\title{
Young Workers in Transition: Explaining the Density Gap by a Life-course Perspective'
}

\section{Laust Høgedahl²}

Associate Professor, Department of Politics \& Society, Aalborg University, Denmark

\section{Rasmus Juul Møberg}

Associate Professor, Department of Sociology \& Social Work, Aalborg University, Denmark

\begin{abstract}
A common challenge for all trade unions in most of the Western world is the growing trade union density gap between young and older workers. In this paper, we examine the generational trade union gap with point of departure in the Danish case. Our data stem from two large surveys (APL II \& III). We find that young workers are not more individualized; to the contrary, unorganized young workers have a growing collective mind-set. Through the lens of a life-course perspective, our data show that young workers have a growing 'fluidic' working life. Many young workers also take jobs in parts of the labor market with weak trade unions representation not allowing them to get in contact with trade unions representatives.
\end{abstract}

\section{KEYWORDS}

Trade unionism / youth organizing / union density / Nordic model of industrial relations

\section{The Nordic labor market models and the trade union generational density gap}

\begin{abstract}
he Nordic labor market models are renowned for their strong social partners and collective bargaining. OECD (2018) has recently linked strong independent collective bargaining with a high macroeconomic performance and good quality of work. The Nordic model of industrial and employment relations is therefore a key factor for growth and welfare for the Nordic countries. However, one of the most important preconditions for the functionality of the Nordic labor market models is a high density for both trade unions and employer organizations. In other words, strong, collective partners are pivotal for high multiple-employer collective bargaining coverage and thus the output of the industrial and employment relations models. The density for employers seems to be rather steady whiles the trade union density has dropped since the peak in mid-1990ies (Høgedahl 2019). If trade unions in the Nordic countries continue to experience a dropping density, they will subsequently lose the representational power and legitimacy to negotiate with their employer counter parts and use collective actions as a tool to demand collective agreements with unorganized employers (Dølvik et al. 2015). A dropping trade union density is thus a challenge for the Nordic welfare models and not only trade unions as organizations.
\end{abstract}

\footnotetext{
${ }^{1}$ You can find this text and its DOI at https://tidsskrift.dk/njwls/index.

${ }^{2}$ Corresponding author: hogedahl@dps.aau.dk.
} 
There are many and complex explanations for the development in the overall trade union density for each of the Nordic countries (Schnabel 2013; Visser 2002). Structural factors such as technology (e.g., robots or artificial intelligence) and internationalization are changing the demand for labor and shifting the 'membership potential' from unskilled workers (and their trade unions) to skilled workers and workers with longer education (Ibsen et al. 2011). Others emphasize institutional factors such as unemployment insurance systems, where trade unions in Finland, Sweden, and Denmark are dependent on the unemployment insurance (Ghent) systems as an important recruiting mechanism (Høgedahl \& Kongshøj 2018). Hence, changes to the unemployment insurance system can also bring changes to the overall trade union density. The scope of this article, however, is the trade union density gap between young and older workers. This is not a new phenomenon (see Kjeldstadli 1997) yet the gap seems to be growing (Caraker et al. 2015). Nor is it a unique Nordic problem but a global trend found in most of the OECD countries (Haynes et al. 2005).

When surveying the existing literature regarding the density gap, as presented in the next section, a wide range of explanations can be identified. These explanations span from a more individualistic orientation towards union membership among the young workers to explanations focusing on structural characteristics of the young worker's jobs, which are often placed in sectors of the labor market where contact to the trade unions for various reasons are less frequent. This hindrance of experience with trade unions can lead to less first-hand knowledge for decision-making. Yet, another perspective potential relevant for explaining the density gap is taken from the life course and youth literature. We see a great potential in this strain of literature because it allows us to combine structural changes with active choice. The main point is that the transition from education to working life is becoming increasingly more complex and 'fluid' with more jumps between the two states. In turn, this contributes to increment of the length of the period of youth as the young person is neither fully educated nor fully integrated on the labor market. In a sense, young workers are in a transition or on migration, as they are not fully prepared to settle down. This goes hand in hand with long running institutional changes in the educational system, characterized by more young people go to university and fewer become skilled laborers.

The research question guiding our analysis: Can the low trade union density for young workers be explained by an active choice based on more individualistic values and/or structural conditions and life course trajectories for young people?

In the following sections, we develop our theoretical argument allowing us to formulate the following hypotheses, which we will test in our empirical analysis:

H1: Young workers are becoming more individualistic in their orientation. Hence, the declining density is a direct consequence of young workers opting-out i.e. an active choice based on value.

$\mathrm{H} 2$ : $\quad$ Structural factors in combination with life course trajectories are placing young workers temporary in parts of the labour market with no or little contact with trade unions.

The two different explanations for the generational density gap point to very different scenarios for trade unions and the Nordic labor market models. If the main reason for the generational density gap is due to ingrained individualistic values incomparable with

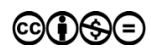


unionization, the prospects for trade unions are bleak. However, if the density gap is due to changes in working life transitions and/or mismatch between trade union strategies and young workers expectations then the trend is reversible (Ibsen et al. 2011). As we argue throughout the article, there is no clear-cut explanation for the declining membership rate among young workers. Rather the explanation should be found in the combination of the different development trends.

In the next section, we survey the state-of-the-art by looking at previous studies. We hereby list a number of explanations and point to the fact that we are able to bring the research further by applying our repeated cross sectional survey data. This allows us to test not only structural and individual variables but also attitudes and experiences among young workers. Later, we then turn to our empirical analysis followed by a final section summarizing our findings.

\section{Can individualistic values explain the decline in union membership?}

As mentioned in the Introduction, a popular explanation for the density gap is because young people today differ from the orientation of previous generations by becoming more individualistic. The consequence is that trade unions are perceived as irrelevant in their focus on collectivism and solidarity (Beck 1983, 1986; Beck \& Beck-Gernsheim 2002). This type of explanations are labeled as generational, where attitudes and values, including attitudes towards union membership, will depend on the general conditions of upbringing to which the individual, like other peers, has been exposed. Generational explanations are further based on a basic assumption that socialization to particular attitudes and values takes place in youth, and are maintained throughout life. The future of collectivity in this perspective is therefore ominous because trade union organizing efforts later in life may have difficulty in changing the already entrenched attitudes towards trade unions. This type of explanation draws on a categorization of young people as a homogeneous group, in the sense that they act in accordance with certain norms and values characterized by individual orientations, given the liberation from the traditions and norms of previous generations. At the same time, the view of being young means that demands for decision-making and choices in relation to the future become a framework-setting condition. In this perspective, younger generations will differ from older generations in their orientation towards trade unions, that is, the younger the individuals, the less support there is for collective solutions. A recent cross-sectional study of Swedish trade union members (Allvin \& Sverke 2020) has found support for the individualization-thesis. They found that younger trade union members to a lesser extent rallied around the solidaric values of the trade unions, and thereby implicitly challenged a central aspect of the Swedish trade unions. The conclusion of the study was that individualization of the working life has led to less support for trade unions. The results indicate a mismatch between the values of trade unions and the expectation of the members, especially the younger members. The argument should not be restricted to explain the development within the unions as in the case of the Swedish study, but as the argument is based on societal changes, it could readily apply to membership of unions, which is the main aim of this article, and not just value orientation when already a member. The hypothesis deduced from the argument above would be that the declining 
interest in the union membership among younger workers relative to older workers can be explained by change in societal values favoring more individualistic values. Empirically, we would expect union density to be less prominent among younger workers compared to older workers.

\section{Structural explanations for the density gap}

Even though the argument of an individualistic youth as a central component in explaining the declining membership density is by no means new cf. the aforementioned study, other studies have been critical of the argument (Aleks et al. 2021; Haynes et al. 2005). The argument is still being advanced, as it resonates well with other theoretical strands especially within management literature (Aleks et al. 2021). Although in society there is a general focus on the individual as well as the individual's free self-expression, it must necessarily be discussed whether a macro-oriented generational explanation causes uniform results in young people's individual orientation towards trade unions and unionization? Recent international research on young people and unionization points out that young people's declining trade union density does not necessarily have to be explained as a rejection of collectivity, solidarity and trade unions (for a good review see Keune 2015). Rather, the lower degree of unionization is due to lack of knowledge as well as the absence of direct experience with trade unions in their working lives (Aleks et al. 2021; Hodder \& Kretsos 2015; Simms et al. 2018; Vandaele 2012).

These findings indicate that the lower trade union density gap can to some extent be attributed to the lack of presence of trade unions and trade unions representatives in young people's everyday lives, and not just a more individualistic orientation among young people. At the same time, it is true that young people's entry into the labor market often takes place in industries that are characterized by a low degree of unionization, low collective agreement coverage, and changeable and short-term employment relationships (Cieslik \& Simpson 2013; Scheuer 2015; Simms et al. 2018). Jensen (2020) points out that sectors with high labor turn over are harder to unionize. From the individual perspective, a possible explanation is that the motivation for trade union membership is low due to the short period of employment. Additionally, the relations between the workers are unstable, which minimizes peer pressure for membership. From a trade union perspective, workers in these industries are harder to identify, and therefore harder to organize, and furthermore, they are at risk of leaving the union. These challenges combined increases the cost of recruiting workers in these industries. Vandaele (2012) points out the seemingly mismatch between young workers expectations and trade union strategies.

In addition, the financial crisis 2008 has in particular had a significant impact on the opportunities and conditions that entry into the labor market offers. This can be seen, among other things, in the reduction in job opportunities, as well as precarious properties of the available jobs (Scheuer 2015; Standing 2014). Research shows that young workers ( $<30$ years) were disproportionally affected by the financial crisis, for example, more young workers became unemployed compared to other workers. The primary drop in employment were among young workers on a standard employment contract (open ended and above 35 weekly hours) (Allmendinger et al. 2013). As a consequence, individual experiences with trade unions will be largely limited. In connection to the 
young workers entry to the labor market, it should be mentioned that the educational background of the young worker in connection with entering the labor market has a strong impact on the opportunities and limitations to which the individual is subjected. Roberts (2012) points out that Beck only to a limited extent has an eye for the significance of the position the young worker occupies on the labor market, as well as how this contributes to situational experiences.

In addition to these conditions for entering the labor market, young people's early working life are also characterized by a high degree of mobility in and out of jobs, amplified by the financial crisis. This is due to several aspects; for example, that young people's problem solving in the labor market is predominantly governed by exit strategies, rather than voice strategies, which other age groups in the labor market make greater use of (Caraker et al. 2015; Hirschman 1970).

In other words, the lower and declining trade union density for young workers compared to older workers cannot necessarily be attributed to that young workers are more individualistic in their orientation. In this line of theorizing, possible membership is more determent by the structural opportunities for exposure to trade unions at the job. The trade unions are in other words absent when the young workers enter the labor market, which in turn complicates the socialization of the young workers. ${ }^{1}$ The young worker is individualized due to the structural position of the job, and not due to individualistic values. Therefore, the decline in propensity to join a trade union is not due to increase in anti-collective values among young workers rather it can be construed as lack of socialization.

These explanations fit well with the social custom theory emphasizing the connection between a strong trade union representation at the local workplace and a reproducing high trade union density (Ibsen et al. 2017; Visser 2002). If young workers are increasingly working in segments of the labor market with weak trade union representation, the social custom effects are equally weak, and thereby the possible socialization effect. This trend is furthermore strengthened by the fact that many young workers have precarious working conditions as mentioned above (Simms et al. 2018) and will often use exit strategies and not voice when exposed to injustice (Caraker et al. 2015).

Alongside the development of the labor market, the literature on life course and youth describes aspects of de-standardization of the life course, especially related to the twenties. Completion of education or starting a family is considered key transitions in the life course and important for all aspects of life, especially for working life. Depending on the particular stage the young worker is in, this will affect the perception of labor market participation and in turn possible orientation towards trade unions. Brückner and Mayer (2005) discuss how different transitions in the course of life (pairing, family formation, the transition between education and the labor market) are to a lesser extent than before linked to specific ages, which means that the age spread at transitions increases. This means that the youth is stretched, and at the same time 'conquers' periods of life that were previously identified with being an adult. Inspired by Frønøs and Brusdal, individuals in this extensive transition can be called 'young adults' (Katznelson et al. 2009). The term covers individuals who are well into their twenties and are still unclear as to the direction of their lives (Nielsen 2020). Tanner and Arnetts (2009) refer to this period as 'emerging adulthood' in an attempt to theoretically capture this period in the life course, where the young person is neither young nor adult. These different contributions to youth research all indicate that the transition to 'adult 
life' is delayed, which is in line with Brückner and Mayers (2005)'s argument for destandardizing transitions between different periods in life. Education and work do not necessarily appear in a linear fashion and in clearly separated periods. Mixture forms emerge where the order is not unambiguous. Participation in the labor market between training courses in the form of sabbatical years and paid work during a training course are examples of such 'temporary' entries into the labor market. This will immediately give different expectations and experiences of the labor market, which will then affect young people's orientation towards trade unions. Nielsen (2020) has shown that young workers in these intermediate positions on the labor market do not plan far ahead; their time horizon is rather short, and they do not worry about long term consequences of the work conditions. This attitude towards work aligns with a preference for exitstrategies as the consequences of a potential job loss is less severe given their short time horizon.

The transition from youth (preparation for working life in the form of education) and working life itself is no longer simple and unambiguous, but often has a longer duration. In this phase of life, many are working (often part time) alongside studying. A development that is supported by the change in the educational background of the workforce, where more and more people participate in higher education. Especially the hotel and restaurant and the retail and service industries have over the last 10-20 years experienced a sharp increase in the proportion of employees who work in parallel with participation in higher education (Høgedahl \& Jørgensen 2016). This only reinforces the problem that young people are often in industries and work areas that traditionally have a reputation for being difficult to organize. The life course theory offers an additional perspective on the decline in trade union membership among young workers as they can be seen on migration throughout their emerging adulthood.

The development of precarious working conditions in particular segments of the labor market and the described changes in the life course patterns in combination strengthen the possible detachment of young workers from union exposure.

Given the transitional nature of young workers, they are harder to recruit. The straightforward solution would be to wait till the young workers finally settle. However, research has shown (Booth 1985; Toubøl \& Jensen 2014) that the probability of joining a trade union decreases with labor market experience and age. Therefore, this might not be a viable solution to the declining membership among young workers.

\section{Survey data from the Danish case}

The empirical analyses are based on data from the two large-scale surveys from 2002 and 2014 (APL II and III). The APL surveys (see Bild et al. 2007; Caraker et al. 2015) are cross-sectional surveys, both of which contain responses from more than 2200 employees, and are representative of the active Danish workforce between 18 and 65 years of age who have labor market participation as their primary activity. Full-time students were as a consequence excluded from the sampling frame. The response rates were $53.6 \%$ in 2002 and $40.2 \%$ in 2014 . However, no serious bias in the material was discovered after testing the representivity. Both surveys contain respondents that are members and non-members of trade unions. The analysis in this paper focuses primarily on young people between the ages of 21 and 30, who answered the APL questionnaire

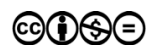


in either 2002 or 2014. Young people under the age of 21 have been excluded due to too few respondents and thus great statistical uncertainty. In our analyses, we will take a closer look at what characterizes young employees in relation to education, connection to the labor market and experiences with trade unions, as well as how these factors can contribute to the explanation of the relationship between trade union membership and individualization. This is possible because the APL studies from 2002 and 2014 include a number of identical questions and response categories. As both studies are reasonably representative for the total active labor market force with respect to organizational factors, age, gender, and so forth, it is possible to compare changes over time (Donsbach \& Traugott 2007).

When comparing trade union membership across time it is important to take into account the development of the labor market. In 2002, the employment rate was $75.9 \%$, which increased to $77.4 \%$ in 2006. Around the onset of the financial crisis in 20082009 , the employment rate decreased to $73.5 \%$. The employment rate continued to decline until 2013 (70.8\%). In 2014, the employment rate increased to $71.1 \%$. Prior to 2002, the employment rate was relatively stable around $76 \%$ (OECD 2021). Thus, the labor market contexts during the collection of the survey differed. In 2002, the economic situation in Denmark was stable and booming. In 2014, the economy was still struggling with the aftermath of the financial crisis in 2008-2009. The economic downturn affected different age groups disproportionally. Allmendinger et al. (2013) have shown that the employment possibilities changed for young workers, that is, full-time employment decreased and more precarious job positions increased in numbers for these young workers. These different economic situations around the data collection are likely to have an effect on the answers of the respondents.

\section{Analysis}

The empirical question this article sets out to answer is twofold: First and foremost, we will address and discuss whether or not young workers are increasingly more individualistic, which in turn will increase the notion that trade unions are consider obsolete as a collective entity for solving the challenges faces by workers in the current labor markets. The descriptive analysis will primarily address Hypothesis 1 on the changes in value orientation of young people towards more individualistic orientated values, and partly address changes in labor market attachment over time. These changes are often associated with young people taking up or seeking jobs at parts of the labor market, which have little or no contact with trade unions (H2). Following this initial descriptive analysis, we will turn to analyzing the generational differences in union membership. The analysis primarily focuses at age differences in 2014, where we find the largest discrepancy between positive orientation towards trade unions, heterogeneity of labor market attachment, and trade union membership. Therefore, APL III data from 2014 serves as the best case for discussion of the theoretical aspects of the paper. However, occasional comparisons with the APL II data will be made to further points of the primary analysis (APL III data). The logistic regression analysis will be framed in terms of mediation analysis (see Figure 1). We are aware that cross sectional data limits the possibility for empirically claiming the temporal order exposure-mediation-outcome as this would require panel data measuring the same individuals over time. Even doing the 
analysis on a pooled dataset (APL II and APL III) would not alleviate this shortcoming. However, the analysis will still be a valid test of whether or not age-differences in union membership can be explained away by taking into account individual characteristics and labor market attachment of the individual. The empirical question of interest is: 'How much of the generational differences in trade union membership can be explained by the direct effect of generation on membership and how much of the generational difference is mediated via positions on the labour market?'

Figure I Analytical model.

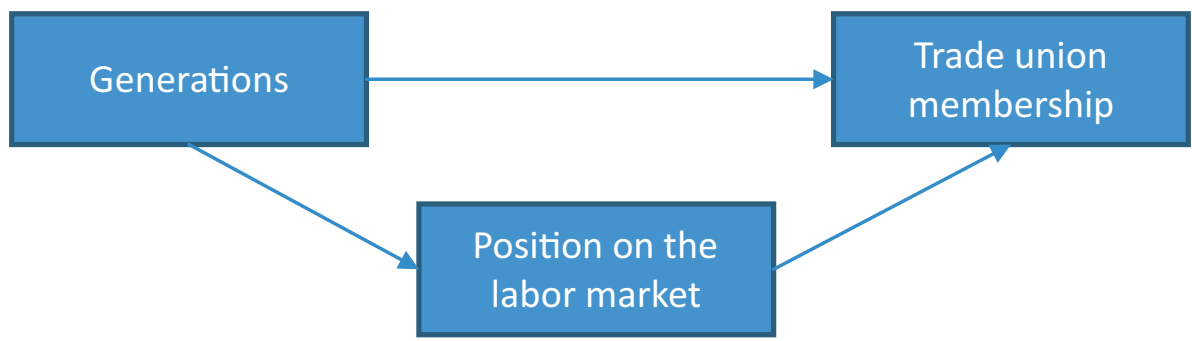

The direct effect would lend support to the thesis that generational differences, that is, the younger generations are more individualistic in the orientation towards labor unions. Whereas a strong indirect effect mediating the generational differences in membership would support the thesis that exposure and opportunities for trade union contact is the explanation for membership or lack hereof as discussed above.

\section{Outcome variable}

The outcome variable in the analysis is whether or not the individual at the moment of survey is a member of trade union. The measurement does not include information on membership of unemployment insurance. Therefore, the analysis of the trade union membership does not distinguish between trade union members who are and are not members of the associated unemployment insurance fund (i.e., the Ghent system). Nor does the measure of trade union membership differentiate between traditional trade unions and so-called yellow trade unions (for more on this phenomenon please see Ibsen et al. 2013). Because the main dependent variable is dichotomous, the regression analysis used in the latter part of the analysis will be binary logistic regression. In addition, age differences in predicted probabilities are presented in the analysis.

In the quantitative methods, literature caution has been raised when comparing coefficients from different logistic regression models (Mood 2010). The reason is that a change in coefficient may be a result of controlling for confounding; however, changes may also be attributed to rescaling bias, which occur if the confounding variable have an independent effect on the outcome variable (Karlsson et al. 2012; Kohler et al. 2011). Therefore, the user-written program KHB (Karlson/Holm/Breen) for Stata 16 has used to ensure that cross-model comparison is not compromised by rescaling bias (Karlsson et al. 2012; Kohler et al. 2011). 
The KBH analysis also facilitates calculation of how much of the generational effect on membership that is explained by the indirect effect, understood as workers position on the labor market.

\section{Measures}

The main independent variable of interest is generations measured in 10 years intervals. Respondents below the age of 21 years are excluded from the analysis since the majority of these respondents did not have labor market participation as their primary occupation. The age variable is divided in the five intervals $21-30$ years of age, 31-40 years of age, 41-50 years of age, 51-60 years of age, and finally above 60 years of age. The last age category is a selected age category both due to self-selection into early retirement possible at the age of 60 and old age pension possible at the age of 65 . Rendering the active labor market participants in this age category a highly selected group.

The following variables are part of the operationalization of the 'position on the labour market', which constitutes the measurement of the indirect effects, mediating the generational differences in union membership. This set of variables contains information on level of education, contractual hours, positioning of hours in the day, social custom at the workplace and sector. All variables that characterize different aspects and possibilities for employment and more importantly possible contact to trade unions.

Level of education is measured in six levels. No vocational education (this category includes respondents who have completed compulsory schooling and high school), Vocational education ( 1 year duration), Vocational education (3-4 year duration), and higher education subdivided into three categories, short, medium, and long duration. The level of education provides insights into the possibilities regarding employment. Informed by the theorization of youth and the education-labor market transition, the no vocational category can, especially for many of the youngest workers, be seen an indication of temporary employment between different educations. The period of emerging adulthood which for many is extended well up in the twenties with no clear-cut transition from education to work. In fact, in this, the two states are often combined. In a Danish context, Nielsen (2020) has shown that the young adult in this intermediate period is more prone to risk taking, have a narrow time perspective regarding work life conditions, and uses an exit rather voice strategy when conditions become disadvantageous as discussed above. This complicates the recruitment and organizing processes of the trade unions.

The labor market is becoming increasingly diverse regarding employment conditions (Scheuer 2017; Standing 2010). Weekly hours worked is another indicator of this. The measurement of average weekly hours (on average less than 30, 30-36, 37-38, 39-42, 43-48 hours, and more than 48 hours) is an empirical indication of the diversity in the work force. Deviation from the norm (37-38 hours a week) can be seen as atypical employment, especially less than 30 hours a week is often associated with positions on the labor market where contact with trade unions is less frequent or membership is not seen as an option at all.

Irregular hours measured as a binary variable with regular hours during the day (8-18) and irregular hours outside the 8-18 period.

Sector is central in understanding differences in the trade union density. Traditionally, the trade unions have highly divergent success when it comes to the recruitment 
of potential members. The service sector, retail sector, and the hotel and restaurant hospitality sector are traditionally sectors in which trade unions struggle to gain foothold, and at the same time, this is where many young people find their entry into the labor market, especially young adults apart from migrant workers. Employment within sectors with low trade union density would result in a minimal trade union exposure for the young adult entering the labor market lowing the effect of social customs.

The variables mentioned are indicators of possible exposure to trade unions seen through the position on the labor market and not lived experience of encounter with trade unions as such. In the APL-surveys, we have asked whether or not it causes grievances from organized colleagues if a colleague at the workplace is not organized. This is an indication of social customs in the workplace, and therefore direct contact with trade unions. The variable is measured on a five-point scale from 'to a high extent' - 'to a very low extent' to cause aversion. Hereby, we are able to measure the perceived effects of social custom thus test pervious results by Ibsen et al. (2017) using administrative data. Ibsen et al. (2017) find a clear effect between union density at work place level and membership propensity.

Finally, gender, measured as male and female, will be introduced in the analysis to account for the effects on the gender-segregated labor in Denmark. Previous studies have shown that especially sectors such as education (primary, secondary schooling) and the hospital sector employ a majority of female workers (Caraker et al. 2015). At the same time, these sectors have a strong tradition for union membership since many are public employed with high collective agreement coverage.

\section{Descriptive analyses}

Table I Development in generational trade union density over time

\begin{tabular}{|c|c|c|c|c|c|c|}
\hline \multirow[b]{2}{*}{ Age group } & \multicolumn{2}{|c|}{$\begin{array}{c}\text { Union membership } \\
2002(\%)\end{array}$} & \multicolumn{4}{|c|}{$\begin{array}{c}\text { Union membership } \\
2014(\%)\end{array}$} \\
\hline & Non-member & Member & Total & Non-member & Member & Total \\
\hline $21-30$ years & 25.4 & 74.6 & 413 & 33.7 & 66.4 & 315 \\
\hline $31-40$ years & 18.9 & 81.1 & 581 & 22.0 & 78.0 & 505 \\
\hline $4 \mid-50$ years & 11.5 & 88.5 & 653 & 19.6 & 80.4 & 704 \\
\hline $51-60$ years & 9.9 & 90.1 & 513 & 12.5 & 87.5 & 922 \\
\hline above 61 years & 19.4 & 80.6 & 67 & 12.0 & 88.0 & 276 \\
\hline Total & 15.9 & 84.1 & 2227 & 18.5 & 81.5 & 2722 \\
\hline
\end{tabular}

Pearson $\mathrm{chi}^{2}(4)=55,7744 \operatorname{Pr}<0.001$.

Pearson $\mathrm{chi}^{2}(4)=82,704 \mathrm{I} \operatorname{Pr}<0.001$.

In both 2002 and 2014, we find that union member density increases with increasing age, with the exception of the above 61 years of age in 2002 . However, the result reported of worker above the age of 61 years both in 2002 and 2014 should be analyzed with caution as they are a selected group. Therefore, the respondents remaining on the labor market are not representative of the age group as such. 
Still, the union density is relatively high; $90.1 \%$ among the age group 51-60 years in 2002 down to $74.6 \%$ among the age group 21-30 years. In 2014, the age difference in union density is more outspoken. From $87.5 \%$ among the age group $51-60$ years to $66.4 \%$ among the age group $21-30$ years old. The different trade union density between the age groups, with lower density for the younger age groups are highly significant in both years (Chi ${ }^{2}$-test, $\mathrm{p}<0.001$ for both years)

Looking at the union density across 2002-2014 within the individual generation (comparing the age group 21-30 in 2002 with the age group 31-40 in 2014, etc.) the level of union density is overall characterized by stability, that is, the small differences in density across time reported in Table 1 are not statistically significant (see appendix 1 ). This result supports the notion that the foundation of union membership is laid around the period of entry to the labor market, and remaining stable in the generation over time (Booth et al. 2010; Visser 2002). ${ }^{2}$ In addition, a decline in trade union density among the youngest age group (21-30 years of age) over time from $74.6 \%$ to $66.4 \%$ in 2014 is identified $\left(\mathrm{Chi}^{2}\right.$-test, $\mathrm{df}=1$, value $\left.=5.8764 \mathrm{p}=0.015\right)$.

If the trend identified in the APL-surveys is not reversed, the trade unions will eventually be become extinct. Moreover, these results are, on the outset, in line with the individualization-hypothesis, that is, young workers are becoming less and less prone to enlist in the trade unions. Even though, the individualization-hypothesis as a viable explanation for the decline in trade union density among young workers is still being debated (Aleks et al. 2021). Several studies (Keune 2015; Vandaele 2016), including Aleks et al. (2021) have pointed out if would be a mistake to assume that declining union density is the result of the increasing anti-union persuasion among the youth of today. The lack of knowledge or encounter with trade unions officials in the daily work life has been advanced as possible explanations.

However, the APL-survey results support the claims that declining trade union density cannot attributed to increasing anti-union persuasion among the youth of today. What we find is that young people in 2014 to a markedly higher extent perceive trade unions to be necessary for securing the interests of the workers compared respondents of the same age group in $2014\left(\mathrm{Chi}^{2}\right.$-test, $\mathrm{df}=4$, value $\left.=25.48, \mathrm{p}<0.001\right)$.

Table 2 Trade unions are necessary for securing the interests of the workers (\%), 21-30 years of age

\begin{tabular}{lccccccc}
\hline & Year & $\begin{array}{c}\text { Agree } \\
\text { to a high } \\
\text { degree }\end{array}$ & Agree & $\begin{array}{c}\text { Neither } \\
\text { agree nor } \\
\text { disagree }\end{array}$ & Disagree & $\begin{array}{c}\text { Disagree } \\
\text { to a high } \\
\text { degree }\end{array}$ & Total \\
\hline \multirow{2}{*}{ all } & 2002 & 27.1 & 33.8 & 19.7 & 11.2 & 8.2 & 376 \\
\hline \multirow{2}{*}{ Members } & 2014 & 41.6 & 33.7 & 16.2 & 5.6 & 3.0 & 303 \\
\hline \multirow{2}{*}{ Non-members } & 2002 & 31.5 & 36.6 & 17.6 & 10.3 & 4.0 & 273 \\
\cline { 2 - 8 } & 2014 & 47.1 & 35.3 & 10.3 & 4.9 & 2.5 & 204 \\
\hline
\end{tabular}

Pearson $\mathrm{chi}^{2}(4)=25,4763 \operatorname{Pr}<0.001$ (all).

Pearson $\mathrm{chi}^{2}(4)=16,8199 \mathrm{Pr}=0.002$ (members).

Pearson chi² ${ }^{2}$ ) $=16,8736 \mathrm{Pr}=0.002$ (non-members). 
Respondents answering totally and partially agree to the question: 'Trade unions are necessary for securing the interests of the workers' increase from $60.9 \%$ in 2002 to $75.3 \%$ in 2014 among the 21-30 years of age. The results point in the different direction than ascribed by the individualization-hypothesis. The youth of today (2014) are not compared to older generations more anti-trade union in their orientation. On the contrary, there is a raising acknowledgment among younger respondents that collective action in some form has to be taking in order to secure workers interests. This increment in acknowledgment can in addition be found not only among young trade union members, but more importantly also among young non-members $\left(\mathrm{Chi}^{2}\right.$-test, $\mathrm{df}=4$, value $=$ $16.82, \mathrm{p}=0.002$ ). More than six out of 10 in 2014 agree to the question, which was only true for $41.7 \%$ of non-members in 2002 . The same positive increase can be found among members $\left(\mathrm{Chi}^{2}\right.$-test, $\mathrm{df}=4$, value $\left.=16.87, \mathrm{p}=0.002\right)$.

Other factors must be affecting the trade union density including structural changes. We find that the labor marked segment where the respondents of the age group 21-30 years find employment, have changed over time. Looking at average weekly hours worked, we find a decline in what in most general agreements constitutes the norm (37-38 weekly work hours).

Table 3 Hours worked on average (\%), age group 21-30 years

\begin{tabular}{cccccccc}
\hline & $\mathbf{- 3 0}$ hours & $\mathbf{3 0 - 3 6}$ & $\mathbf{3 7 - 3 8}$ & $\mathbf{3 9 - 4 2}$ & $\mathbf{4 3 - 4 8}$ & above 48 hours & total \\
\hline 2002 & 4.3 & $\mid 1.1$ & 63.9 & $\mid 1.1$ & 3.8 & 5.8 & 396 \\
\hline 2014 & 25.2 & $\mid 4.4$ & 46.4 & 8.5 & 3.3 & 2.3 & 306 \\
\hline
\end{tabular}

Pearson $\operatorname{chi}^{2}(5)=73,3188 \operatorname{Pr}<0.001$.

In 2002, 63.9\% worked on average 37-38 hours a week. In 2014, this is the case for less than half of the respondents in the age group. At the same time, there is a large increase in the share who work less than 30 hours on average.

The result is a clear indication of a more fragmented connection to labor market for an increasing share of the youngest generation. This development in the labor market attachment for younger age group reflects the development well documented in the literature on precarization discussed earlier (Simms et al. 2018). What is, in addition, evident from this line of research is, that younger worker to a larger extent compared to older worker are employment in positions that can be characterized as precarious (Ibid; Nielsen 2020; Scheuer 2017). At the same time, the nature of precarious employment complicates the recruitment process, as contact point between the trade unions and the individual worker become more scares. Consequently, the position on the labor market should be seen as a possible explanation of membership or lack hereof.

Another indication of that young workers to a lesser extent meet the trade unions in their daily working life can be found when looking closer at young workers experience with social customs.

The respondents were asked to what extent it triggers aversion among the majority of colleagues on your workplace if a colleague is not a member of the trade union.

Even though, the social customs was limited in 2002, there were $13.7 \%$ who replied 'to a very large extent' or 'to a large extent' to the question. In 2014 , only $4.5 \%$ in the age group (21-30 years) have replied to a very large extent or 'to a large extent' to the same question. The results show that the experiences of social custom, that is, the expectation 
Table 4 Trade union social customs at workplace level (\%), age group 21-30 years

\begin{tabular}{lcccccc}
\hline & $\begin{array}{c}\text { To a very high } \\
\text { degree }\end{array}$ & $\begin{array}{c}\text { To a high } \\
\text { degree }\end{array}$ & Partly & $\begin{array}{c}\text { To a small } \\
\text { degree }\end{array}$ & $\begin{array}{c}\text { To a very } \\
\text { small degree }\end{array}$ & total \\
\hline 2002 & 6.5 & 7.2 & 17.3 & 20.4 & 48.6 & 387 \\
\hline 2014 & 3.1 & 1.4 & 26.4 & 19.3 & 49.8 & 295 \\
\hline
\end{tabular}

Question: 'Can one say that it triggers aversion among the majority of colleagues on your workplace if a colleague is not a member of the trade union'.

Pearson $\mathrm{chi}^{2}(4)=22,9477 \operatorname{Pr}<0.001$.

of trade union membership from other colleague is on the decline. This suggests that the explanation of the decline trade union density is derived from possible encounters with the unions rather than young workers orientation towards unions. In other words, position on the labor market has more to offer in term of explanation, than age of the respondent or the generation to which he or she belongs. This is an important finding.

The descriptive analysis illustrates the complexity of explaining trade union membership for young workers. Trade union membership is declining from 2002 to 2014; at the same time, there is an increase in young workers who find the presence of trade unions relevant for securing the interests of the workers. This implies that decline in membership cannot necessarily be attributed to a different value orientation of the young workers compared to older workers. The descriptive analysis further shows changes in the labor market attachment between 2002 and 2014, for example, atypical employment is more common for the young workers (21-30 years) in 2014 compared to young workers in 2002. In addition, they experience less social custom. Labor market possibilities will to a large extent be affected by the economic cycles (see previous discussion of the years of data collection) when discussing the implications of the results.

In the following part of the analysis, we will address questions of the opposite hypothesis between the individualistic value orientation of the young workers and the position of the young worker as an explanation for trade union membership. The outset for the analysis will be APL III data where two logistic regressions will be fitted. Model 1 will include age as an explanation for the trade union membership. Model 2 will include age and in addition the following control variables gender, level of education, working hours, irregular hours, social custom, and sector. The primary objective of model 2 is whether or not the inclusion of the control variables, which are indications of the position on the labor market can explain away the crude age difference already presented in Table 1.

The results presented in Table 5 (The full logistic regressions can be found in the appendix) show a clear generational effect (the crude model). The effect increases with increasing age. This could be interpreted as an indication of the younger generations are more individualistic, and therefore less inclined to join the trade unions as they embody a more collectivistic approach.

However, when the control variables are introduced into the model no statistically significant difference between the three youngest generations (21-30, 31-40, and 41-50) can be identified. In other words, the generational difference between the three youngest generations is due to the position on the labor market. Seventy-one percent of the crude difference between the age group 21-30 and 31-40, and 59\% of crude difference between age group 21-30 and 51-60 is explained by the position on the labor market (see KHB-analysis in appendix). The results support the hypothesis that the position on 
Table 5 Logistic regression - Trade union membership in 2014

\begin{tabular}{|c|c|c|c|c|}
\hline \multirow[b]{2}{*}{ Member } & \multicolumn{2}{|c|}{ Model I } & \multicolumn{2}{|c|}{ Model 2} \\
\hline & Odds Ratio & $P>z$ & Odds Ratio & $P>z$ \\
\hline \multicolumn{5}{|c|}{$21-30$ years (baseline) } \\
\hline $31-40$ years & 1.80 & 0.000 & 1.15 & 0.470 \\
\hline $4 I-50$ years & 2.08 & 0.000 & 1.24 & 0.246 \\
\hline $51-60$ years & 3.56 & 0.000 & 2.08 & 0.000 \\
\hline 61 years & 3.73 & 0.000 & 2.50 & 0.001 \\
\hline _cons & 1.97 & 0.000 & 0.18 & 0.000 \\
\hline Pseudo $R^{2}$ & 0.0301 & & 0.117 & \\
\hline$N$ & 2722 & & 2418 & \\
\hline
\end{tabular}

Source: APL III data.

Model I: unadjusted.

Model 2: controlled for gender, education, hours, irregular hours, social custom, and sector.

the labor market and thereby exposure to trade unions rather than individualistic value orientated is the explanation at least for the abovementioned age groups. ${ }^{3}$

Perhaps a more intuitive presentation of age differences in trade union membership is predicted probabilities, which will be presented in Figure 2 (based on results from model 1) and Figure 3 (based on results from model 2) in Table 5.

Figure 2 Predicted probabilities for model I.

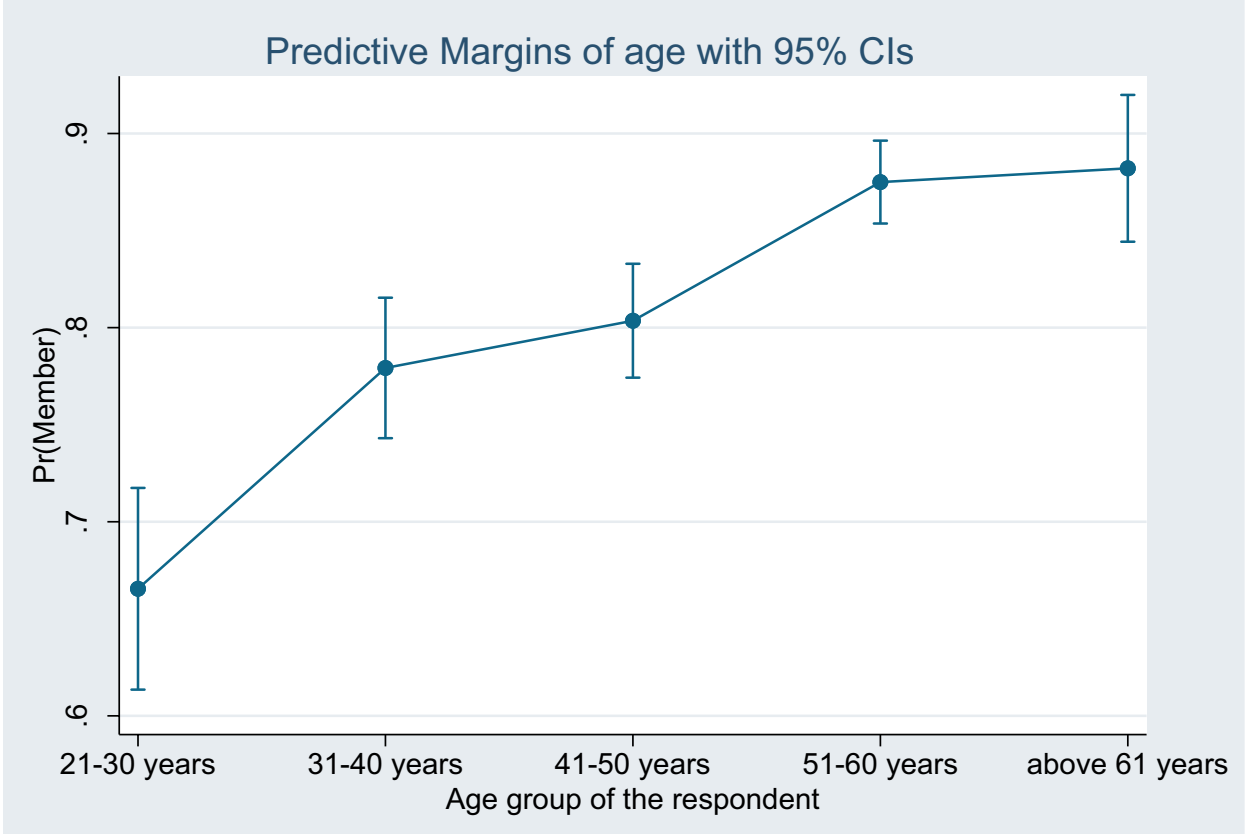


The predicted probabilities in Figure 1 matches the results presented in Table 1 and we clearly see that the youngest age group in the unadjusted model (model 1, Table 5) have a remarkable lower predicted probability (66.4\%) for being a trade union member compared to all the other age-groups with the two oldest age groups having the highest predicted probability for being a trade union member.

Figure 3 Predicted probabilities for model 2.

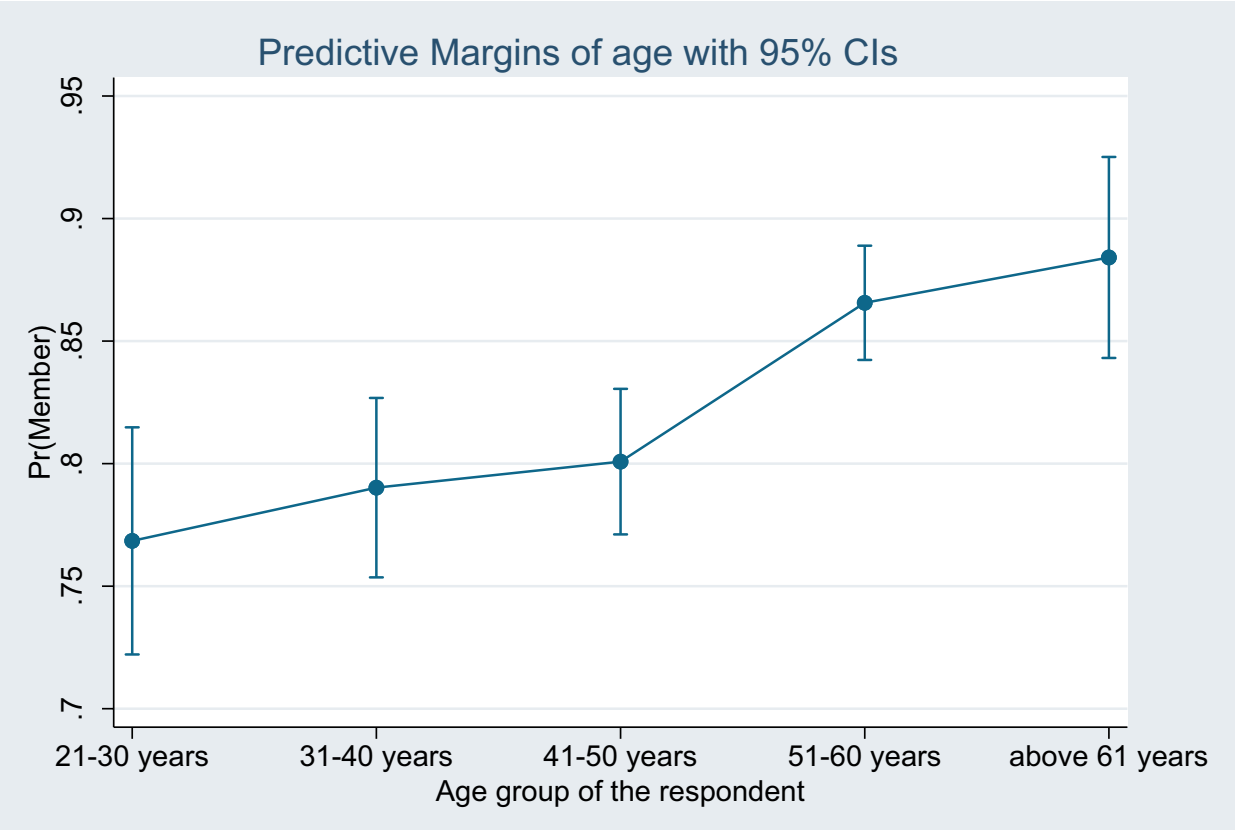

However, when controlling for gender, education, hours, irregular hours, social custom, and sector, there is no longer a difference in predicted probability for being a trade union member, when comparing the three youngest age groups. Even though the predicted probabilities numerically are different, they are not statistically different as their CI are overlapping.

However, some generational difference in trade union membership remains between the youngest (21-30) and the oldest generations (workers aged 51 and above), even after the introduction of the variables indicating the position on the labor market. The explanation of enduring age difference could potentially be that the older the workers are the more selected since workers with more peripheral connection to the labor market from these generations are retired from the labor force, whereas this is not the case among the youngest age groups.

\section{Conclusions and discussion}

In this paper, we set out to explain the trade union generational density gap by applying cross sectional data from the Danish case collected through two large surveys. 
This enables us to test a combination of different independent variables (including structural, institutional, and individual measures) in relation to our outcome variable indicating trade union membership. In addition, our repeated cross-sectional design makes it possible to track changes from 2002 to 2014. Initially, our research shows a clear generational effect on trade union density since young workers are increasingly not trade union members. This trend would and should support the notion that young workers are increasingly becoming individualized to an extent that a trade union membership is not relevant. However, as soon as we introduce other variables, it becomes clear that the participation and affiliation to the labor market are much more important. The youth segment is changing since more people are receiving longer education in combination with a growing precarious employment that are especially pronounced among young workers. We also find that many young workers are found in parts of the labor market with low trade union density and collective agreement coverage. This means few shop stewards and other trade union representatives. The lack of trade union representation presents itself as weak social custom effects of strong norms. Young workers are also more likely to exit than voice making transition between jobs more frequent. When taking these variables into account the generational effect vanishes for between the age groups 21-30,31-40, and 41-50 in 2014. There are still differences between the young workers (aged 21-30) and the oldest age groups on the labor market (51-60 and 61 years of age). However, the difference is greatly reduced by the inclusion of the variables indicating the position on the labor market. The explanation of enduring age difference could potentially be that the older the workers are the more selected since workers with more peripheral connection to the labor market are retired from the labor force among the older age group, whereas this is not the case among the youngest age groups. The generational effect is also being challenged when surveying the changes in attitudes towards trade unions among young workers. We find an increase positive attitudes from 2002 to 2014. This includes not only thus already members of a trade union but also young non-members. Some the explanation for this increase might come from a periodic effect due to two very different contexts that our surveys have been conducted. In 2002, the economy was booming, and in 2014, we still partly suffered from the long-term economic effects of the financial crisis from 2008. We know that trade union membership is procyclical, which might be part of the explanation why young workers in 2014 have a more positive view on trade unions compared to similar aged young workers in 2002 where the economy was at an upturn that lasted until 2008 when the financial crisis hit. However, since the actual membership rate declined from 2002 to 2014, we consider this possible periodeffect to be less important for the main arguments of the article. Nevertheless, there is no doubt that further research into procyclical membership and youth should be explored. Especially, due to the fact, that young workers are disproportionally affected in terms of employment during a crisis. The analysis is in this regard limited by only having two data points, as this does not allow for distinction between trends or cyclic development of values towards the trade unions. However, the fact that both members and non-members are showing increasing positive attitudes clearly refute a growing individualization.

Our data cannot cover the supply side of the equation. We clearly see that structural changes on the labor market combined with a more segmented group of young workers are important factors for a lower trade union density. However, trade union strategies - or

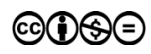


lack of - might also prove very important explaining variables. The theoretical insights from life course theory and youth research points to the fact that a growing number of young workers are often in transition with a high job mobility. More research should be done on the effect of life course transitions between education and labor market participation and how the contact or non-contact with trade unions affect future membership. At present, many trade union might be reluctant to spend too many resources on this segment since many are just passing through hanging around for a short period. Young workers in transition with a high job turnover are more costly to recruit for the trade unions (Schnabel 2013). However, as Tapia and Turner (2018) show, trade union can play an important role giving 'voice' to young workers, yet, this is only possible through relative openness and active encouragement of unions to the leadership development of young workers. Organizing effort seem to work through the persistence and creativity of groups of young workers in promoting their own engagement However, since research clearly shows that trade union membership early in ones working life means a higher probability of membership later in life, it is important to organize young workers even though they are temporary visiting. Young workers are also heavily based on emerging labor market such as the platform economy. These growing industries are of strategic importance for the Nordic labor movement since it fits poorly with Nordic labor market model with a clear definition of workers and employers.

\section{References}

Aleks, R., Saksida, T., \& Wolf, A. S. (2021). Hero or Villain? A Cohort and Generational Analysis of How Youth Attitudes Towards Unions Have Changed over Time, British Journal of Industrial Relations 59(2): 532-567. doi: https://doi.org/10.1111/bjir.12571.

Alivin, M., \& Sverke, M. (2000). Do new generations imply the end of solidarity? Swedish unionism in the era of individualization, Economic and Industrial Democracy 21(1): 71-95. doi: https://doi.org/10.1177/0143831X00211004.

Allmendinger, J., Hipp, L., \& Stuth, S. (2013). Atypical employment in Europe 1996-2011 (No. P 2013-003). WZB Discussion Paper.

Beck, U. (2000). The Brave new world of work, New York: Polity Press.

Beck, U. (1986). Risikogesellschaft - Auf dem Weg in eine andere Moderne, Edition Suhrkamp, Frankfurt.

Beck, U. (1983). "Jenseits von Klasse und Stand? Soziale Ungleichheit, gesellschaftliche Individualisierungsprozesse und die Entstehung neuer sozialer Formationen und Identitäten”, pp. 33-74 in Kreckel, R. (eds.): Soziale Ungleichbeiten, Sozale Welt Sonderheft, Göttingen.

Beck, U. \& Levy, D. (2012). “Cosmopolitanized Nations: Re-imaging Collectivity in Work Risk Society”, Theory, Culture \& Society 30(2): 3-31. doi: https://doi.org/10.1177/ 0263276412457223.

Bild, T., Caraker, E., Jørgensen, H., Lassen, M., Møberg, R. J., Scheuer, S. (2007). Arbejdsliv og politik - signalement af lønmodtagere $i$ det 21. arrhundrede [Working life and politics - signaling of wage earners in the 21st century], Nyt fra Samfundsvidenskaberne, København.

Booth, A. L. (1985). The free rider problem and a social custom model of trade union membership, The Quarterly Journal of Economics 100(1): 253-261. doi: https://doi.org/ $10.2307 / 1885744$. 
Booth, J., Budd, J. W. \& Munday, K. M. (2010). First-timers and Late-bloomers: Youthadult unionization differences in a cohort of the U.S. Labor Force, Industrial and Labor Relations Review 64(1): 53-73. doi: 2F001979391006400103" https://doi.org/10.1177/ 001979391006400103.

Brückner, H., \& Mayer, K. U. (2005). De-standardization of the life course: What it might mean? And if it means anything, whether it actually took place?, Advances in Life Course Research 9: 27-53. Doi: https://doi.org/10.1016/S1040-2608(04)09002-1.

Cieslik, M., \& Simpson, D. (2013). Key Concepts in Youth Studies, London: Sage

Donsbach, W., \& Traugott, M. W. (Eds.). (2007). The SAGE handbook of public opinion research, London: Sage.

Haynes, P., Vowles, J. \& Boxall, P. (2005). Explaining the younger-older worker union density gap: evidence from New Zealand, British Journal of Industrial Relations 43: 93-116. doi: https://doi.org/10.1111/j.1467-8543.2005.00346.x.

Heinz, W. R., \& Krüger, H. (2001). Life Course: Innovations and Challenges for Social Research, Current Sociology 49(2): 29-53. doi: https://doi.org/10.1177/001139210104 9002004.

Hirschman, A. O. (1970). Exit, Voice, and Loyalty: Responses to Decline in Firms, Organizations and States, Cambridge, MA: Harvard University Press.

Hodder, A. \& Krestos, L. (2015). 'Young workers and unions: Context and overview'. In A. Hodder and L. Krestos (eds.), Young Workers and Trade Unions: A Global View, London: Palgrave Macmillan, pp. 1-15.

Høgedahl, L. (2020). The Danish Labour Market Model: Is the Bumblebee Still Flying? In P. M. Christiansen, J. Elklit, \& P. Nedergaard (Eds.), The Oxford Handbook of Danish Politics (pp. 559-576), Oxford University Press. Oxford Handbooks

Høgedahl, L., \& Kongshøj, K. (2017). New trajectories of unionization in the Nordic Ghent countries: Changing labour market and welfare institutions, European Journal of Industrial Relations 23(4): 365-380. doi: https://doi.org/10.1177/0959680116687666.

Høgedahl, L., \& Jørgensen, H. (2017). Udviklingen i regulering af løn- og arbejdsvilkår set i et lønmodtagerperspektiv, Samfundsoekonomen (1): 18-24.

Ibsen, C. L., Toubøl, J., \& Jensen, D. S. (2017). Social customs and trade union membership: A multi-level analysis of workplace union density using micro-data, European Sociological Review 33(4): 504-517. doi: https://doi.org/10.1093/esr/jcx055.

Katznelson, N., Illeris, K., Nielsen, J. C., Sørensen, N. U., \& Simonsen, B. (2009). Ungdomsliv: mellem individualisering og standardisering. [Youth life - Between individualization and standardization], Frederiksberg: Samfundslitteratur.

Jensen, C. S. (2020). Labour market segmentation and mobility as determinants of trade union membership: A study from Denmark, Economic and Industrial Democracy 41(4): 824-838. doi: https://doi.org/10.1177/0143831X17738115.

Jørgensen, C. H. (2009). Fra uddannelse til arbejde - ikke kun en overgang [From education to work - not just a transition], Tidsskrift for Arbejdsliv (1): 67-86. doi: https://doi. org/10.7146/tfa.v11i1.108766.

Keune, M. (2015). Younion - Union for Youth. Final Report: Trade unions and young workers in seven EU countries, Brussels.

Karlsson, K. B., Holm, A., Breen, R. (2012). Comparing regression coefficients between same-sample nested models using logit and probit: A new method, Sociological Methodology 42: 286-313. doi: https://doi.org/10.1177/0081175012444861.

Kjeldstadli, K. (1997). "Solidaritet og individualitet”, pp. 9-26 in Ning de Connick-Smith m.fl. (red.): Historiens kultur, Museum Tusculanum.

Kohler, U., Karlsson, K. B., Holm, A. (2011). Comparing coefficents of nested nonlinear probability models, The Stata Journal 11(3): 420-438. doi: https://oi.org/10.1177/ $1536867 X 1101100306$. 
Mood, C. (2010). Logistic regression: Why we cannot do what we think we can do, and what we can do about it, European Sociological Review 26(1): 67-82. doi: https://doi. org/10.1093/esr/jcp006.

OECD (2018). OECD Employment Outlook 2018, Paris: OECD Publishing.

OECD (2021). "Labour: Labour market statistics", Main Economic Indicators (database), doi: https://doi.org/10.1787/data-00046-en (Accessed June 7, 2021).

Roberts, S. (2012). One step forward, one step Beck: a contribution to the ongoing conceptual debate in youth studies, Journal of Youth Studies 15(3): 389-401. doi: https://doi.org/10. 1080/13676261.2012.663896.

Schnabel, C. (2013). Union membership and density: Some (not so) stylized facts and challenges, European Journal of Industrial Relations 19(3): 255-273. doi: 10.1177/ 0959680113493373.

Scheuer, S. (2015). How Precarious Is Contingent Work?-Non-salary Aspects of the Employment Relationship of Contingent Employees in Denmark, Journal of Management and Strategy 6(2): 14-30. doi: https://doi.org/10.5430/jms.v6n2p14.

Simms, M., Eversberg, D., Dupuy, C., \& Hipp, L. (2018). Organizing young workers under precarious conditions: What hinders or facilitates union success, Work and Occupations 45(4): 420-450. doi: https://doi.org/10.1177/0730888418785947.

Standing, G. (2014). A precariat charter: From denizens to citizens, A\&C Black.

Tailby, S., \& Pollert, A. (2011). Non-unionized young workers and organizing the unorganized, Economic and Industrial Democracy 32(3): 499-522. doi: https://doi.org/10.1177/ $0143831 X 10388532$.

Toubøl, J., \& Jensen, C. S. (2014). Why do people join trade unions? The impact of workplace union density on union recruitment, Transfer: European Review of Labour and Research 20(1): 135-154. doi: https://doi.org/10.1177/1024258913516902.

Vandaele, K. (2012). Youth representatives' opinions on recruiting and representing young workers: A twofold unsatisfied demand? European Journal of Industrial Relations 18(3): 203-218. doi: https://doi.org/10.1177/0959680112452692.

Visser, J. (2002). Why fewer workers join unions in Europe: A social custom explanation of membership trends, British Journal of Industrial Relations 40(3): 403-430. Doi: https:// doi.org/10.1111/1467-8543.00241.

Waddington, J., \& Kerr, A. (2002). 'Unions fit for young workers?' Industrial Relations Journal 33: 298-315. doi: https://doi.org/10.1111/1468-2338.00237.

\section{Notes}

${ }^{1}$ Another aspect of socialization, which will not be addressed in this article is intergenerational transmission of trade union membership [see Bryson and Davies (2019) for a recent discussion].

${ }^{2} \mathrm{APL}$ is a repeated survey, and not panel data, therefore the claim of stability can be ascertained at the age group and not on the individual level.

${ }^{3}$ Rerunning the same models from Table 5 but for the year 2002 (analysis not shown) did produce a comparable age difference in membership. However, in the adjusted model, they age difference largely remained. The difference between $21-30$ years and $31-40$ years where only significant at $p=0.104$. The difference between $21-30$ years and 41-50, 51-60 years were statistically significant. The oldest age group were not different from youngest in the adjusted model. But this is largely a power problem as there are only 67 respondents from 2002 in the oldest age group. The results indicate that position on the labor market cannot explain away the age difference as is the case in 2014 data. 
Appendix I

\begin{tabular}{|c|c|c|c|}
\hline Comparing the membership density over time & Chi' ${ }^{2}$-test & df $=$ & $\mathbf{p}$ \\
\hline $21-30$ (2002) with $31-40(2014)$ & 1.4973 & I & 0.221 \\
\hline $31-40$ (2002) with 4I-50 (2014) & 0.0916 & I & 0.762 \\
\hline $51-60(2002)$ with above $60(2014)$ & 0.3513 & I & 0.553 \\
\hline
\end{tabular}

Appendix 2. Logistic regression

\begin{tabular}{|c|c|c|c|c|c|c|}
\hline \multirow[b]{2}{*}{ member } & \multicolumn{2}{|c|}{ Model I } & \multicolumn{2}{|c|}{ Model Ia } & \multicolumn{2}{|c|}{ Model 2} \\
\hline & Odds Ratio & $\overline{P>z}$ & Odds Ratio & $\overline{P>z}$ & Odds Ratio & $\mathbf{P}>\mathbf{z}$ \\
\hline \multicolumn{7}{|l|}{ 21-30 år (baseline) } \\
\hline $31-40$ år & 1.80 & 0.000 & 1.27 & 0.215 & 1.15 & 0.470 \\
\hline $41-50$ år & 2.08 & 0.000 & 1.34 & 0.105 & 1.24 & 0.246 \\
\hline $51-60$ år & 3.56 & 0.000 & 2.30 & 0.000 & 2.08 & 0.000 \\
\hline $61 \mathrm{arr}-$ & 3.73 & 0.000 & 2.65 & 0.000 & 2.50 & 0.001 \\
\hline female & & & 1.23 & 0.108 & 1.25 & 0.086 \\
\hline \multicolumn{7}{|l|}{ No education (baseline) } \\
\hline I-year vocational & & & 2.15 & 0.005 & 2.14 & 0.007 \\
\hline Three-year vocational & & & 2.81 & 0.000 & 2.92 & 0.000 \\
\hline Short higher education & & & 1.70 & 0.016 & 1.87 & 0.005 \\
\hline Medium higher education & & & 1.59 & 0.012 & 1.68 & 0.006 \\
\hline Long higher education & & & 1.21 & 0.333 & 1.35 & 0.138 \\
\hline \multicolumn{7}{|l|}{ less than 30 hours (baseline) } \\
\hline 30-36 hours & & & 1.96 & 0.001 & 1.93 & 0.002 \\
\hline 37-38 hours & & & 2.60 & 0.000 & 2.54 & 0.000 \\
\hline $39-42$ hours & & & 2.26 & 0.001 & 2.23 & 0.001 \\
\hline 43-48 hours & & & 3.27 & 0.000 & 3.22 & 0.000 \\
\hline$>48$ hours & & & 2.02 & 0.034 & 2.18 & 0.023 \\
\hline irregular hours & & & 1.58 & 0.003 & 1.59 & 0.003 \\
\hline \multicolumn{7}{|l|}{ Agricultural osv. (baseline) } \\
\hline Process Industry & & & 4.06 & 0.000 & 3.66 & 0.000 \\
\hline Construction & & & 4.73 & 0.000 & 4.45 & 0.000 \\
\hline Trade, retail, restaurants, hotel & & & 1.45 & 0.307 & 1.54 & 0.233 \\
\hline Transport & & & 3.98 & 0.001 & 3.49 & 0.004 \\
\hline Bank-, insurance, finance & & & 2.83 & 0.010 & 2.80 & 0.011 \\
\hline Public administration & & & 6.88 & 0.000 & 6.82 & 0.000 \\
\hline Teaching and nursing & & & 5.63 & 0.000 & 5.44 & 0.000 \\
\hline Private service & & & 2.19 & 0.025 & 2.09 & 0.037 \\
\hline Other & & & 4.56 & 0.002 & 4.18 & 0.003 \\
\hline
\end{tabular}




\begin{tabular}{|c|c|c|c|c|c|c|}
\hline \multirow[b]{2}{*}{ member } & \multicolumn{2}{|c|}{ Model I } & \multicolumn{2}{|c|}{ Model Ia } & \multicolumn{2}{|c|}{ Model 2} \\
\hline & Odds Ratio & $\mathbf{P}>\mathbf{z}$ & Odds Ratio & $\overline{P>z}$ & Odds Ratio & $P>z$ \\
\hline Strong social custom & & & & & 3.73 & 0.000 \\
\hline _cons & 1.97 & 0,000 & 0.19 & 0.000 & 0.18 & 0.000 \\
\hline Pseudo $R^{2}$ & 0.030 & & 0.103 & & 0.117 & \\
\hline $\mathrm{N}$ & 2722 & & 2481 & & 2418 & \\
\hline
\end{tabular}

Appendix 3. Crude and adjusted logistic regression on union membership based on the decomposition using the KHB-Method

\begin{tabular}{lccc}
\hline Age group & Coef. & P > z & effect mediated \\
\hline $21-30$ (baseline) & & & \\
\hline $31-40$ & 0.48 & 0.0120 & $70.8 \%$ \\
Crude & 0.14 & 0.4700 & \\
Adjusted & 0.34 & 0.005 & \\
Difference & & & $59.3 \%$ \\
\hline $41-50$ & 0.53 & 0.0030 & \\
Crude & 0.21 & 0.2460 & \\
Adjusted & 0.31 & 0.011 & $36.6 \%$ \\
Difference & & & \\
\hline $51-60$ & 1.16 & 0.0000 & \\
Crude & 0.73 & 0.0000 & \\
Adjusted & 0.42 & 0.001 & $34.1 \%$ \\
Difference & & 0.0000 & \\
\hline $61-$ & 1.39 & 0.0010 & \\
Crude & 0.92 & 0.000 & \\
Adjusted & 0.47 & & \\
Difference & &
\end{tabular}

APL III data. 